DOI: https://doi.org/10.31392/NZ-npu-144.2019.15

УДК 378 147:004.92

Малежик П. М.

\title{
ФОРМУВАННЯ ДОСЛІДНИЦЬКИХ УМІНЬ МАЙБУТНІХ ІТ-ФАХІВЦІВ В ПРОЦЕСІ ВИКЛАДАННЯ ТЕХНІЧНИХ ДИСЦИПЛІН
}

У статті розглядаються теоретико-методичні засади формування досліднищьких умінь майбутніх IT-фахівців на прикладі викладання технічних дисциплін. Запропонована структурна модель формування досліднищьких умінь. Показано, що проведення практичних та лабораторних занять, які побудовані на трунтовній дослідницькій основі сприяє виробленню у майбутніх IT-фахівців професійної замікавленості, розвитку у них логічно-наукового мислення, а також виробленню професійних умінь, здійснювати аналіз проблем та шукати шляхи їх подолання. Важливим фактором формування дослідницької діяльності майбутніх фахівиів з комп'ютерних наук є участь у наукових проблемних проектах кафедри, стажування у ІT-компаніях.

Ключові слова: дослідницькі уміння, ІТ-фахівці, технічні дисципліни, формування умінь, структурна модель.

У законі № 928-VIII від 25.12.2015 “Про вищу освіту” у розділі VI статті 26 зазначено "провадження наукової діяльності шляхом проведення наукових досліджень і забезпечення творчої діяльності учасників освітнього процесу, підготовка наукових кадрів вищої кваліфрікації і використання отриманих результатів в освітньому процесі" [1]. На сьогоднішній день модернізація освітнього процесу в Україні тісно пов'язана з упровадженням у систему освіти компетентнісного підходу формування професійних компетентностей, однією 3 яких $є$ дослідницька компетентність. У Великій Хартії університетів зазначено, що викладання та дослідницька робота в університетах мають бути неподільні для того, щоб навчання в них відповідало постійно змінюваним потребам i запитам суспільства та науковим досягненням [2].

Формування дослідницьких умінь, $€$ актуальною проблемою сучасної педагогіки і психології, оскільки у наш час інтелектуальна дослідницька діяльність $€$ головною умовою росту виробничих сил людства.

Ґрунтом для формування та розвитку інтелектуальних умінь $€$ підготовка студентів у вищих навчальних закладах до активних дій в непередбачуваних, професійних, наукових та інших проблемних ситуаціях. Сфрормований фахівець сучасного рівня повинен вміти самостійно знаходити найоперативніші шляхи до вирішення наукової проблеми, теоретично розраховувати, використовувати нові наукові дані, на їх основі організовувати нові дослідження, користуватися сучасними джерелами інформації, а також бачити суть будь-якого профресійного завдання.

Забезпечення наукової діяльності вищих навчальних закладів здійснюється через безпосередню участь учасників навчально-виховного процесу в науково-дослідних роботах та організацію наукових, науковопрактичних, науково-методичних семінарів, конференцій, олімпіад, конкурсів, науково-дослідних, курсових, дипломних та інших робіт учасників навчально- 
виховного процесу.

Вміння використовувати інформаційні технології кардинально змінює виробничу діяльність людини, створюючи нові умови для подальшого розвитку дослідника, дослідницької компетентності в формуванні особистості. Від сучасних навчальних закладів вимагається не просто включення дослідницьких методів в освітню практику, а цілеспрямована робота 3 формування і розвитку культури дослідницької діяльності, здатності до її проведення протягом всього творчого життя. Формування дослідницьких компетентностей в студентів у процесі неперервної професійної освіти надасть можливість підготовити гармонійно розвинутого, динамічного і успішного фахівця, здатного вирішувати широке коло професійних задач, використовуючи наукові методи. Отже, на сьогодні проблема фрормування дослідницьких компетентностей в студентів вищих закладів освіти набуває особливого значення.

Аналіз наукових публікацій показав, що існують різні методологічні і теоретичні погляди на трактування поняття дослідницьких компетентностей. Так у своїх роботах такі вчені-педагоги, як В.О.Болотов, І. О. Зимня, С.І. Осипова, Ю. В. Соляніков, О.А. Ушаков, А. В. Хуторськой, та ін. дослідницьку компетентність вважають ключовою [3, 4]. В. А. Адольф, А. А. Деркач, Т.А. Смоліна та ін. розглядають їі як складову професійної компетентності, а Б. С. Гершунський, В. В. Лаптєв - як складову загальної та професійної освіченості.

Методичні засади формування дослідницької компетентності в майбутніх учителів із різних спеціальностей досліджували: М. І. Жалдак, Ю. С. Рамський, М. В. Рафальська, О.В. Співаковський - 3 інформатики, М. В. Архипова, А. В. Пригодій, С. М., - з технологій, С. А. Раков - з математики, В. Д. Шарко з фрізики тощо [5-9].

Теоретичне обґрунтування та побудова моделей формування дослідницької компетентності майбутніх фахівців у навчальному процесі 3ВО подано в роботах М. С. Голованя, М. В. Архипової [10, 6]. Роботи останніх років, що стосуються цієї проблематики, зокрема проблемі фрормування дослідницької компетентності у майбутніх інженерів-програмістів, пов'язані 3 дослідженнями М. О. Вінника, Н.В.Осипової, Ю.Г. Тарасіч [11, 12] та ін. Наукові праці та розробки зазначених дослідників частково сприяли вдосконаленню професійної підготовки різних спеціальностей, проте, поза увагою залишилися питання формування дослідницької компетентності в майбутніх IT-фрахівців.

Мета статті - побудова та теоретичне обґрунтування структурної моделі формування дослідницької компетентності майбутніх фахівців з IT-галузі в процесі їх технічної підготовки.

Для цього нами були окреслені завдання: з'ясувати змістовну сутність та структуру дослідницької компоненти у майбутніх IT-фахівців; розробити структурну модель формування дослідницької компетентності у майбутніх ІTфрахівців. 
Методи дослідження. Для реалізації поставленої мети та виконання завдань були використані теоретичні методи: аналіз, узагальнення та систематизація методичної психолого-педагогічної літератури, ресурсів Інтернет з проблеми дослідження, аналіз освітніх та навчальних програм, інтерпретаційно-аналітичний метод.

Поява широкого спектру напрямів розвитку IT вимагає наявності фрахівців з різними профресійними знаннями і компетентностями. Основу підготовки ITфахівців у ЗВО складають навчальний план; варіативні частини освітньопрофресійної програми (ОПП - перелік нормативних навчальних дисциплін із зазначенням часу відведеного для їх вивчення та форм підсумкового контролю 3 кожної навчальної дисципліни), освітньо-кваліфрікаційної характеристики (ОКХ - основні вимоги до професійних якостей, знань і умінь фахівця, які необхідні для успішного виконання професійних фрункцій). Формування основного рівня курсів, зокрема підготовки з спеціальності 122 комп'ютерні науки на фракультеті інформатики НПУ імені М. П. Драгоманова, передбачає вивчення низки суто технічних дисциплін, таких як “Теорія електричних та магнітних кіл”, “Комп'ютерна схемотехніка”, “Архітектура комп'ютерних систем", “Операційні системи”, “Комп'ютерні мережі”, які вивчаються студентами протягом не менше трьох семестрів і мають значний потенціал для послідовного формування технічних компетентностей. Чітка послідовність вивчення навчальних дисциплін, форми і періодичність виконання індивідуальних завдань та відповідний контроль визначаються структурно-логічною схемою підготовки. Значну частину в процесі навчання займають практико-технічні та лабораторні заняття, які побудовані на ґрунтовній дослідницькій основі. Таким чином, сучасне освітнє середовище 3 його нормативною базою $є$ сприятливою основою для формування дослідницької компетентності у майбутніх IT-фрахівців.

Загалом система компетентнісного підходу до професійного розвитку фахівця містить ключові, або над предметні компетентності, які формуються під час засвоєння змісту всіх навчальних дисциплін [3].

В нашому дослідженні компетентність розглядаємо, як “інтегральну якість особистості, яка проявляється в її загальній здатності та готовності до діяльності, що ґрунтується на знаннях і досвіді, які набуті в процесі навчання та орієнтовані на самостійну й успішну участь у діяльності" [15].

Дослідницька компетентність - це така сукупність знань, дослідницьких умінь, навичок і способів діяльності, яка дозволяє студенту займати позицію дослідника.

В пропонованій нами структурній конструкції моделі дослідницької компетентності (рис. 1) передбачено використання підходів - компетентнісного та діяльнісного. Також використані наступні дидактичні принципи: - наочності, систематичності, послідовності, науковості, доступності, зв'язку теорії 3 практикою; - проблемності, педагогічного стимулювання, орієнтації на майбутню професійну діяльність. 


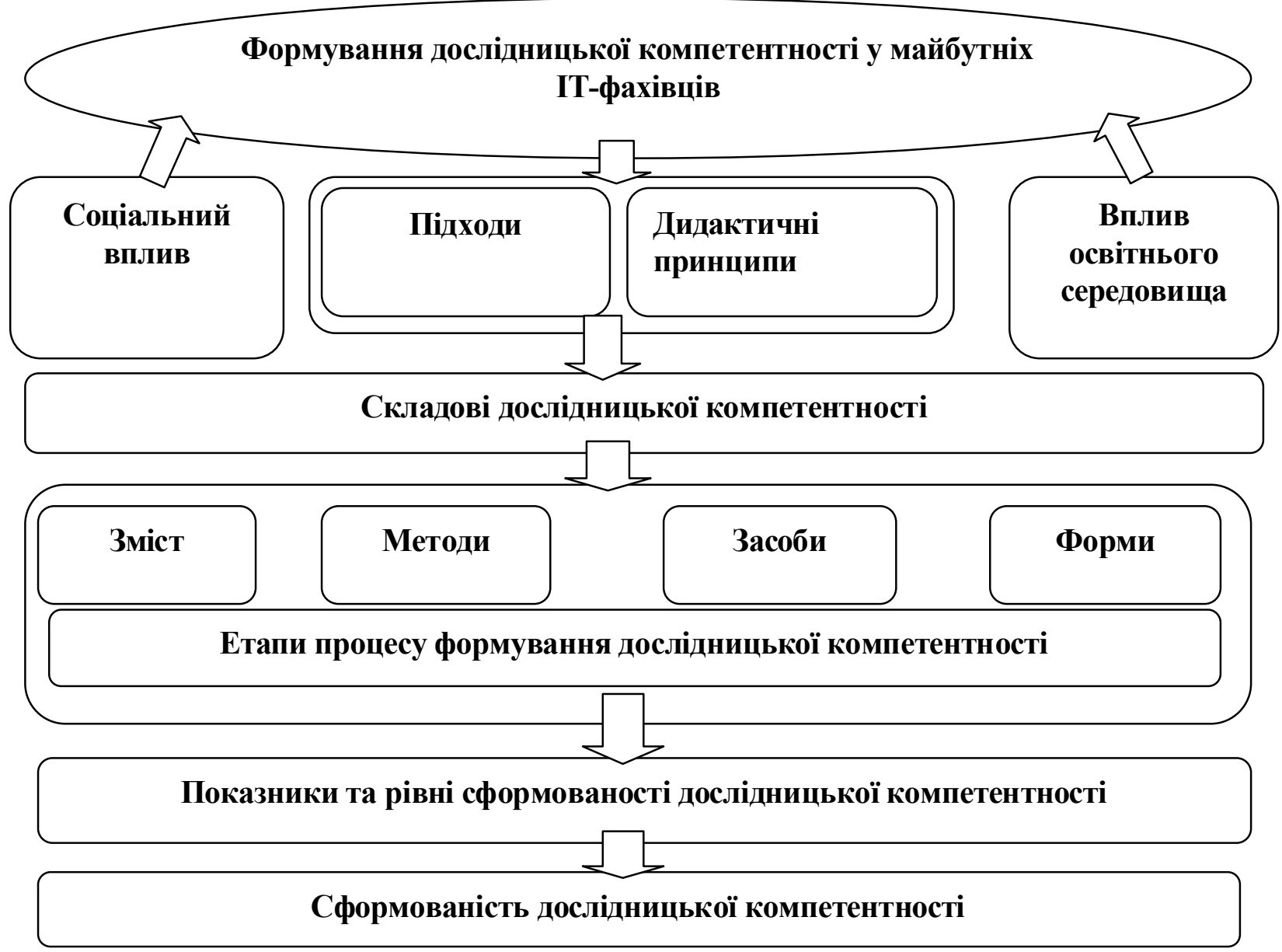

Рис. 1. Структурна модель формування дослідницької компетентності

Структурна конструкція містить такі складові дослідницької компетентності:

- когнітивну, або профресійно-особістнісну компоненту, яка забезпечує готовність фрахівця до гностичної функції і припускає високий рівень інтелектуальних здібностей, творчий підхід до сприйняття і аналізу наукової інфрормації, вибір певної наукової позиції, тощо;

- світоглядну компоненту, яка розглядається як розуміння, що пояснює його суть $з$ точки зору педагогічної науки. Дослідницька компетентність в межах цієї компоненти містить поняття методологічної компетентності майбутнього IT-фрахівця, як носія профресійних цінностей;

- орієнтувальну і технологічну компоненти, що визначаються як діяльності, оскільки вони містять сукупність таких спеціальних якостей, як уміння формулювати проблему, організовувати дослідницький процес, створювати проекти, здійснювати науковий пошук та аналізувати його результати.

- комунікативну компоненту, як уміння чітко і ясно фрормулювати свої думки, відстоювати вибір власної позиції, вміти входити в контакт з іншими учасниками 
дослідження, володіти уміннями привселюдного виступу [13, с. 92-94].

Зазначені компоненти дослідницької компетентності майбутніх IT-фрахівців нами розглядалися за трьома рівнями сформованості: низький, достатній, високий.

Сама технологія фрормування представлена як сукупність змісту, методів, засобів та фрорм, які планомірно і послідовно застосовуються в процесі підготовки майбутніх IT-фрахівців.

Основними методами, що використовуються для фрормування дослідницької компетентності у майбутніх ІТ-фрахівців $є$ :

- метод проб і помилок вважається природженим методом мислення людини. Цей метод ще називають методом перебору варіантів;

- метод мозкового штурму - оперативний метод рішення проблеми на основі стимулювання творчої активності, при якому учасникам обговорення пропонують висловлювати якомога більшу кількість варіантів рішень, навіть самих фантастичних. Після цього із загальної кількості висловлених ідей відбирають найбільш вдалі, які можуть бути практично використані;

- метод евристичних підходів - спосіб пошуку нових технічних рішень на основі використання фонду евристичних підходів;

- метод морфологічного аналізу - метод рішення творчої задачі за допомогою комбінаторики та шляхом побудови морфологічної матриці отримати всі теоретично можливі варіанти реалізації об'єкта з необхідною головною функцією.

Зазначимо, що позитивним в першому методі є: відсутність необхідності навчання методу, методична простота, задовільна ефективність рішення простих задач. До недоліків слід віднести: утрудненість рішення складних задач специфікою методу, відсутність алгоритму мислення і стандартних прийомів рішення, має місце майже хаотичний перебір варіантів. Метод мозкового штурму - інтуїтивний метод, спочатку рішення не відрізняється високою оригінальністю, але з часом типові, шаблонні рішення вичерпуються, і в учасників починають виникати незвичайні ідеї. Метод залежить від психологічної атмосфери і активності обговорення, на ефективність прийняття правильних рішень, в значній мірі, впливає дослідницька компетентність керівника. Метод евристичних підходів базується на підказках - фонді евристичних прийомів, проте вичерпність або невідповідність фронду евристичних прийомів рішенню конкретної творчої задачі приведе до проблемної ситуації, що сприятиме до подальшої самоактуалізації студента у пошуках вірного рішення. Метод морфологічної комбінаторики базується на побудові матриці всіх варіантів рішення технічної задачі, після візуалізації варіантів відбираються найбільш суттєві, після чого поєднання варіантів перевіряються на працездатність і найбільшу ефективність. Цей метод досить громіздкий і має певні складності у виборі основних варіантів.

Серед засобів формування дослідницької компетентності поряд 3 традиційними застосовуються засоби IKT: комп'ютери, мережі, електронні ресурси, хмарні інформаційно-аналітичні сервіси системи Google. Останні 
дозволяють користувачеві отримувати якісну та кількісну інформацію про результати освітньої діяльності та наукових досліджень, що відображені у наукових публікаціях, статистику цитованості даних публікацій, аналітичні дані щодо наукометричних показників та ін.

У науково-дослідницькій діяльності студентів у навчальному процесі використовуємо такі форми організації, як лекції, семінари, практичні та лабораторні роботи, спецкурси, виробничу практику, написання курсових та дипломних проектів. Науково-дослідницька діяльність поза навчальним процесом здійснюється у формі самостійної роботи, у науково-дослідних проектах університету, роботи в наукових проблемних гуртках, участі в наукових конференціях, публікаціях наукових матеріалів, статей та ін.

Важливим, на наш погляд в процесі формування дослідницької компетентності $\epsilon$ чітке дотримання наступності етапів. Процес фрормування складається з таких етапів:

1) діагностико-прогностичного;

2) інформаційного;

3) практичного;

4) творчо-евристичного.

Поступовий перехід від простих форм науково-дослідницької роботи до більш складних надає можливість студенту динамічно розвиватися та удосконалювати свої уміння і навички.

До складу критеріїв оцінювання рівня сорормованості дослідницької компетентності майбутніх ІТ-фрахівців у процесі технічної підготовки були включені зазначені вище складові: когнітивна; світоглядна; орієнтувальна і технологічна; комунікативна. Показники сорормованості за трьома рівнями наведені в табл. 1.

Таблиця 1

Показники та рівні сформованості дослідницької компетентності

\begin{tabular}{|c|c|c|}
\hline Рівні & Показники & Оичінювання \\
\hline Високий & 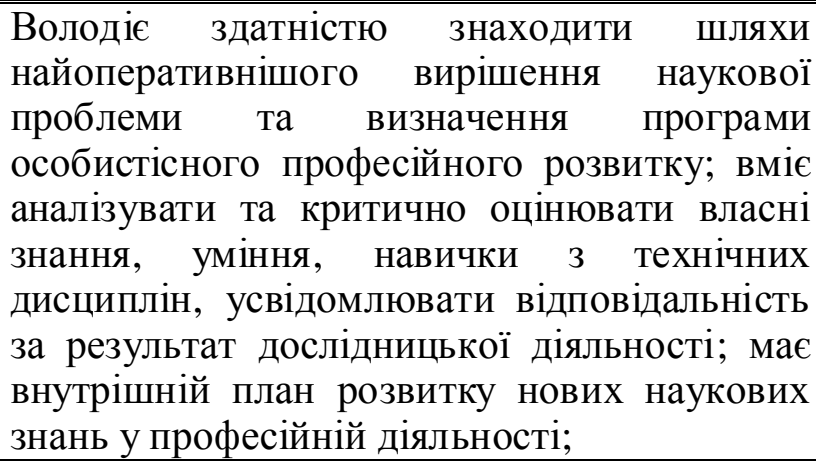 & $\begin{array}{l}\text { Курсові та дипломні } \\
\text { про екти. Тестування, } \\
\text { індивідуальне завдання } \\
\text { (метод проекту, метод } \\
\text { кейсів), завдання } \\
\text { практичного характеру. }\end{array}$ \\
\hline Достатній & $\begin{array}{l}\text { Вміє визначати мету } \\
\text { діяльності, планувати таку діяльність для } \\
\text { досягнення результату, } \\
\text { отриманий результат; аналізувати, виділяти } \\
\text { головне. }\end{array}$ & $\begin{array}{l}\text { Курсові та дипломні } \\
\text { проекти. Тестування, } \\
\text { індивідуальне завдання } \\
\text { (метод проекту, метод } \\
\text { кейсів), завдання } \\
\text { практичного характеру }\end{array}$ \\
\hline
\end{tabular}




\begin{tabular}{|c|c|c|}
\hline Pівні & Показники & Оиінювання \\
\hline Низький & $\begin{array}{l}\text { Вміє визначати } \\
\text { діяльності та та оцінювати дослідницької } \\
\text { результат, здатний до розуміння та аналізу } \\
\text { своїх помилок. }\end{array}$ & $\begin{array}{l}\text { Курсові та дипломні } \\
\text { проекти. Тестування, } \\
\text { індивідуальне завдання } \\
\text { (метод проекту, метод } \\
\text { кейсів), завдання } \\
\text { практичного характеру }\end{array}$ \\
\hline
\end{tabular}

Нами використовується практика залучення студентів фракультету інформатики НПУ імені М.П.Драгоманова, зокрема спеціальності “Комп'ютерні науки”, до науково-дослідницької діяльності в проблемних групах, а також до написання курсової роботи при вивчені дисципліни “Комп'ютерні системи" починаючи з другого курсу, що допомагає їм визначитися 3 напрямком їх наукових інтересів.

Формування і розвиток науково-дослідних умінь студентів здійснюється в певній мірі при вивченні дисципліни “Основи наукових досліджень”, яка побудована на застосуванні інноваційних освітніх технологій, з використанням інтерактивних методів навчання. На заняттях враховується компетентнісний підхід у професійному становленні майбутніх IT-фрахівців. Тому особлива увага приділяється індивідуальному підбору завдань, їх практико-орієнтованій спрямованості та актуалізації самостійної роботи.

Ці аспекти організації професійної підготовки студентів впливають на вибір основних видів освітніх технологій, що використовуються при вивченні дисципліни “Основи наукових досліджень”. Виокремимо такі складові:

- практична складова - діяльно-орієнтоване навчання студентів. Технології засновані на діяльності включають в себе аналіз ситуацій, ділові ігри, моделювання професійної діяльності в навчальному процесі, контекстне навчання; організацію професійно-орієнтованої навчально-дослідницької роботи. Дана технологія спрямована на формування системи професійних практичних умінь, що дасть можливість підготувати IT-фрахівця, здатного кваліфіковано здійснювати пошук та вирішувати профресійні завдання.

- особистісна складова - особистісно-орієнтоване навчання. Вивчення дисципліни передбачає можливість вибору для майбутніх IT-фрахівців і подальше виконання ними різних творчих проектів.

- самоосвітня складова - дослідницьке навчання або адаптивна технологія, що заснована на максимальному залученні студентів в індивідуальну самостійну роботу. Забезпечується використанням завдань для самостійної роботи студентів, а також виробленням рекомендацій щодо здійснення самостійної роботи.

Процес навчання включає аудиторні заняття шляхом проведення практичних занять, групові та індивідуальні консультації, поточний контроль отриманих знань, використання різних форм науково-дослідницької діяльності студентів, самостійну роботу, а також проведення самоаналізу.

Формуванню науково-дослідних умінь студентів сприяє широке 
використання в ході освітнього процесу інтерактивних методик навчання, що передбачає конструктивне залучення студентів до навчального процесу, активізацію навчально-пізнавальної діяльності.

Основні цілі які вирішуються при проведенні практичних занять - це закріпити у студентів основні теоретичні положення основ наукових досліджень, виробити уміння аналізу і самостійного організовувати дослідну діяльність стосовно до виниклих суперечок навчального процесу, сприяти вивченню ними необхідної літератури, в тому числі і наукових видань за темою, що розглядається на практичному занятті.

Проведення практичних та лабораторних занять, які побудовані на ґрунтовній дослідницькій основі сприяє виробленню у майбутніх IT-фрахівців професійної зацікавленості, розвитку у них логічно-наукового мислення, а також виробленню професійних умінь, здійснювати аналіз проблем та шукати шляхи їх подолання.

Важливим $є$ й те, що тематика курсових, бакалаврських та магістерських робіт є відповідною до науково-дослідницьких проектів кафедри.

Наведемо типові теми магістерських робіт:

- Розробка Android-додатку для глобального оцінювання підприємств клієнтами.

- Створення інформаційно-аналітичної системи рейтингового оцінювання науково-педагогічних працівників.

- Розробка та впровадження системи охорони та контролю житлового приміщення.

- Соціальна мережа для підприємців з вирішення проблем малого та середнього бізнесу.

- Розробка системи розпізнавання мовлення з використанням сервісів Google.

- Підвищення рівня сорормованості дослідницької компетентності майбутніх IT-фрахівців помітна також і в якісних показниках. Близько 14\% магістрів продовжують діяльність у наукових установах та ЗВО. Значна частина випускників працює у відомих IT-компаніях.

Висновки 3 дослідження і перспективи подальших розробок. Таким чином, формування дослідницьких компетентностей студентів на основі пропонованої моделі, у процесі самостійної роботи надає можливість перейти від пасивного репродуктивного засвоєння знань до активного, продуктивного рівня, що розвиває пізнавальну активність, творче мислення, інтелектуальну активність, продуктивність, оригінальність і гнучкість мислення, винахідливість, уміння побачити проблему, інтуїцію, швидкість розумових реакцій. Проведене дослідження слугуватиме підґрунтям подальшого вивчення проблеми технічної підготовки майбутніх ІТ-фрахівців. Подальшого поглибленого наукового вивчення потребують питання фрормування дослідницької компетентності в процесі вивчення студентами технічних дисциплін.

\section{Використана література:}

1. Закон України №928-VIII від 25.12.2015 “Про вищу освіту” // http://zakon3/rada/gov/ua/laws/show/ 1556/page2 
2. Велика хартія університетів http://zakon4.rada.gov.ua/laws/2984-14

3. Зимняя И. А. Ключевые компетентности как результативно-целевая основа компетентностного подхода в образовании. Москва : Исслед. центр проблем качества подготовки специалистов, 2004. $38 \mathrm{c.}$

4. Хуторской А. В. Технология проектирования ключевых и предметных компетенций. Интернетжурнал “Эйдос”. 2005. декабря. [Електронний ресурс]. Режим доступу: http://www.eidos.ru/ journal/2005/1212.htm.

5. Жалдак М. І., Рамський Ю. С., Рафальська М. В. Модель системи соціально-професійних компетентностей вчителя інформатики. Науковий часопис НПУ імені М. П. Драгоманова. Серія 2. Комп’ютерно-орієнтовані системи навчання. 2009. № 7 (14). С. 3-10.

6. Архипова М. В. Модель формування дослідницької компетентності майбутнього інженерапедагога [Текст]. Вісник Чернігівського державного педагогічного університету імені Т. Г. Шевченка. Педагогічні науки. 2010. Вип. 76. С. 8-11.

7. Пригодій А. В. Організація науково-дослідної роботи студентів на заняттях з дисципліни “Основи наукових досліджень”. Вісник Чернігівського начіонального педагогічного університету. Серія : Педагогічні науки. 2016. Вип. 140. С. 173-175. Режим доступу: http://nbuv.gov.ua/UJRN/ VchdpuP_2016_140_42

8. Раков С. А. Математична освіта: компетентнісний підхід з використанням IКТ : монографія. Х. : Факт, 2005. 360 c.

9. Шарко В. Д. Технології компетентісно-орієнтованого навчання природничих дисциплін. Теоретико-методичні основи вдосконалення системи освіти: дидактичний аспект : колективна монографія / за ред. Г. С. Юзбашевої. Херсон : КВНТЗ “Херсонська академія неперервної освіти”, 2014. C. $13-78$

10. Головань М. С. Модель формування дослідницької компетентності майбутніх фахівців у процесі професійної підготовки [Текст]. Педагогічні науки: теорія, історія, інновачійні технології. 2012. № 5 (23). С. 196-205.

11. Формування дослідницьких компетентностей студентів спеціальності “Програмна інженерія” на прикладі викладання курсу "Групова динаміка та комунікаціі" [Текст] / М. О. Вінник, Н. В. Осипова, Ю. Г. Тарасіч, А. П. Савенко. Наукові праці. 2014. Т. 245. Вип. 233. С. 95-101.

12. Осипова Н. В., Вінник М. О., Тарасіч Ю. Г. Модель формування дослідницької компетентності у майбутніх інженерів-програмістів [Текст]. Інформаційні технології в освіті. 2014. № 20. С. 150-159.

13. Пригодій А. В. Формування дослідницької компетентності майбутніх учителів технологій. Науковий часопис Наиіонального педагогічного університету імені М. П. Драгоманова. Серія 13. Проблеми трудової та професійної підготовки. Вип. 6: Збірник наукових праць. Київ : Вид-во НПУ імені М. П. Драгоманова, 2010. С. 153-156. http://nbuv.gov.ua/UJRN/VchdpuP_2016_140_42

14. Державний класифікатор України Класифікація видів науково-технічної діяльності ДК 015-97 [Електронний ресурс]. Режим доступу : https://zakon.rada.gov.ua/rada/show/va822217-97.

15. Селевко Г. К. Компетентности и их классификация. Народное образование. 2004. № 4. С. 138-143.

16. Максим Подалов. Формирование студенческой исследовательской компетенции посредством основных методов ТРИЗ. Наукові записки. Випуск 98. Серія: Педагогічні науки. Кіровоград : РВВ КДПУ ім. В. Виниченка, 2011. С. 341-343.

\section{References:}

[1] Zakon Ukrainy №928-VIII vid 25.12.2015 "Pro vyshchu osvitu" // http://zakon3/rada/gov/ua/laws/ show/1556/page2

[2] Velyka khartiia universytetiv http://zakon4.rada.gov.ua/laws/2984-14

[3] Zimnyaya I. A. Klyuchevye kompetentnosti kak rezultativno-celevaya osnova kompetentnostnogo podhoda v obrazovanii. Moskva : Issled. centr problem kachestva podgotovki specialistov, 2004. $38 \mathrm{~s}$.

[4] Hutorskoj A. V. Tehnologiya proektirovaniya klyuchevyh i predmetnyh kompetencij. Internet-zhurnal "Ejdos". 2005. dekabrya. [Elektronnij resurs]. Rezhim dostupu : http://www.eidos.ru/journal/ 2005/1212.htm.

[5] Zhaldak M. I., Ramskyi Yu. S., Rafalska M. V. Model systemy sotsialno-profesiinykh kompetentnostei vchytelia informatyky. Naukovyi chasopys NPU imeni M. P. Drahomanova. Seriia 2. Kompiuternooriientovani systemy navchannia. 2009. № 7 (14). S. 3-10. 
[6] Arkhypova M. V. Model formuvannia doslidnytskoi kompetentnosti maibutnoho inzhenera-pedahoha [Tekst]. Visnyk Chernihivskoho derzhavnoho pedahohichnoho universytetu imeni T. H. Shevchenka. Pedahohichni nauky. 2010. Vyp. 76. S. 8-11.

[7] Pryhodii A. V. Orhanizatsiia naukovo-doslidnoi roboty studentiv na zaniattiakh z dystsypliny "Osnovy naukovykh doslidzhen". Visnyk Chernihivskoho natsionalnoho pedahohichnoho universytetu. Seriia : Pedahohichni nauky. 2016. Vyp. 140. S. 173-175. Rezhym dostupu: http://nbuv.gov.ua/ UJRN/VchdpuP_2016_140_42

[8] Rakov S. A. Matematychna osvita: kompetentnisnyi pidkhid z vykorystanniam IKT : monohrafiia. Kh. : Fakt, 2005.360 s.

[9] Sharko V. D. Tekhnolohii kompetentisno-oriientovanoho navchannia pryrodnychykh dystsyplin. Teoretyko-metodychni osnovy vdoskonalennia systemy osvity: dydaktychnyi aspekt : kolektyvna monohrafiia / za red. H. S. Yuzbashevoi. Kherson : KVNTZ "Khersonska akademiia neperervnoi osvity", 2014. S. 13-78

[10] Holovan M. S. Model formuvannia doslidnytskoi kompetentnosti maibutnikh fakhivtsiv u protsesi profesiinoi pidhotovky [Tekst]. Pedahohichni nauky: teoriia, istoriia, innovatsiini tekhnolohii. 2012. № 5 (23). S. 196-205.

[11] Formuvannia doslidnytskykh kompetentnostei studentiv spetsialnosti "Prohramna inzheneriia" na prykladi vykladannia kursu "Hrupova dynamika ta komunikatsii" [Tekst] / M. O. Vinnyk, N. V. Osypova, Yu. H. Tarasich, A. P. Savenko. Naukovi pratsi. 2014. T. 245. Vyp. 233. S. 95-101.

[12] Osypova N. V., Vinnyk M. O., Tarasich Yu. H. Model formuvannia doslidnytskoi kompetentnosti u maibutnikh inzheneriv-prohramistiv [Tekst]. Informatsiini tekhnolohii v osviti. 2014. № 20. S. 150-159.

[13] Pryhodii A. V. Formuvannia doslidnytskoi kompetentnosti maibutnikh uchyteliv tekhnolohii. Naukovyi chasopys Natsionalnoho pedahohichnoho universytetu imeni M. P. Drahomanova. Seriia 13. Problemy trudovoi ta profesiinoi pidhotovky. Vyp. 6: Zbirnyk naukovykh prats. Kyiv : Vyd-vo NPU imeni M. P. Drahomanova, 2010. S. 153-156. http://nbuv.gov.ua/UJRN/VchdpuP_2016_140_42

[14] Derzhavnyi klasyfikator Ukrainy Klasyfikatsiia vydiv naukovo-tekhnichnoi diialnosti DK 015-97 [Elektronnyi resurs]. Rezhym dostupu : https://zakon.rada.gov.ua/rada/show/va822217-97.

[15] Selevko G. K. Kompetentnosti i ih klassifikaciya. Narodnoe obrazovanie. 2004. № 4. S. 138-143.

[16] Maksim Podalov. Formirovanie studencheskoj issledovatelskoj kompetencii posredstvom osnovnyh metodov TRIZ. Naukovi zapiski. Vipusk 98. Seriya: Pedagogichni nauki. Kirovograd : RVV KDPU im. V. Vinichenka, 2011. S. 341-343.

МАЛЕЖИК П. М. Формирования исследовательских умений будущих ИТ-специалистов в процессе обучения техническим дисциплінам.

В статье рассматриваются теоретико-методические основы формирования исследовательских умений будущих ИТ-специиалистов на примере преподавания технических дисииплин. Предложенная структурная модель формирования исследовательских умений. Показано, что проведение практических и лабораторных занятий, которые построены на основательной исследовательской почве, способствует выработке у будущих ИТ-специалистов профессиональной заинтересованности, развития у них логически-научного мылиления, а такэе выработке профессиональных умений, осуществлять анализ проблем и искать пути их преодоления. Ваюным фактором формирования исследовательской деятельности будущих спечиалистов по компьютерным наукам является участие в научных проблемных проектах кафедры, стажировки в ИТ-компаниях.

Ключевые слова: исследовательские умения, ИТ-специалисты, технические дисциплины, формирование умений, структурная модель.

MALEZHYK P. M. Formation of research abilities of future it-professionals in the technical course.

The article deals with theoretical and methodological foundations of forming the research skills of future IT specialists on the example of teaching technical disciplines. The structural model of formation of research skills is offered. It is shown that conducting practical and laboratory sessions, which are based on a thorough research basis, promotes the development of future professional interests of IT professionals, the development of logical and scientific thinking, as well as the development of professional skills, analyze problems and find ways to overcome them. An important factor in the formation of research activities of future computer scientists is participation in scientific problematic projects of the department, internships in IT companies.

Keywords: research skills, IT specialists, technical disciplines, skills formation, structural model. 